\title{
Crime and Mentalities in Early Modern England
}

\author{
Malcolm Gaskill \\ Churchill College, Cambridge \\ Cambridge University Press, 2000
}

Sérgio Paulo Rigonatti ${ }^{1}$
A Universidade de Cambrigde vem publicando uma série de monografias que abordam o período compreendido entre o fim do século XV e o início do XVIII, ou sejam, textos que versam sobre a moderna história britânica. Um dos volumes mais interessantes quer para a psiquiatria forense quer para a psicologia jurídica é o intitulado: Crime and Mentalities in Early Modern England de Malcolm Gaskill.

O autor discorre inicialmente sobre o conceito de "mentalidade", focalizando as dificuldades para estudá-la, na medida em que tal conceito não tem uma existência tangível e temos de descobrí-la nas entrelinhas da documentação investigada. Destaca, com propriedade, que nos séculos em questão, poucas pessoas imortalizaram seus pensamentos em cartas, diários ou livros. Porém, os documentos estudados versavam sobre a natureza do delito e sua incidência, sobre a difusão de crimes, sobre as penas etc...

Após tal introdução, o autor nos remete para os delitos relacionados com a feitiçaria, discorrendo sobre o significado social dessa "arte" e o papel das bruxas na sociedade e na cultura. $\mathrm{O}$ autor analisa as acusações dirigidas contra elas e a figura da feiticeira tal como é descrita na literatura da época.

Os falsários de moedas e seus entreveros com a justiça, bem como o perigo que esse crime constituía para a autoridade da coroa, foram profundamente estudados.O autor comenta o que pensava a população em geral sobre tal crime.

Os homicídios indicam o nível de violência existente na sociedade naquele momento da história moderna das Ilhas Britânicas; a aplicação das penas nesses casos foi investigada com detalhes e, através desses estudos, pode-se delinear a mentalidade da época.

Enfim, esse livro nos mostra o pensamento de uma sociedade nodal na definição do Mundo Ocidental no decorrer dos séculos XV ao XVIII e constitui leitura obrigatória para entendimento não só do pensar jurídico, mas também de sua evolução e das projeções desse conjunto ideológico de pensamento na justiça moderna.

Recebido: 03/03/2004 - Aceito: 08/03/2004

1 Coordenador do Núcleo de Estudos de Psiquiatria Forense e Psicologia Jurídica - NUFOR - Ipq

Endereço para correspondência: Instituto de Psiquiatria, Hospital das Clínicas da Faculdade de Medicina da Universidade de São Paulo (HC-FMUSP), Rua Ovídio Pires de Campos, $785-3^{\circ}$ andar

- São Paulo - SP CEP 05403-010, e-mail: ect@hcnet.usp.br 